\title{
RECOGNIZING THE EFFECT OF PRIOR KNOWLEDGE IN ECONOMICS AND COHESION DEVICES ON COMPREHENDING BUSINESS ENGLISH TEXTS
}

\author{
Fachrukrozie Kodri (Corresponding Author) \\ Perbanas Institute/IKPIA Perbanas \\ Jl. Perbanas Karet, Kuningan, Setiabudi, Jakarta \\ Phone: 081932398064 email: fachruk@perbanas.id
}

\begin{abstract}
Comprehending a text successfully is influenced by many factors. Texts will be easier to comprehend if learners are able to identify these essential factors. This study was aimed at recognizing the effect of using prior knowledge in economics and cohesion devices in comprehending business English texts. The research was conducted in Faculty of Economics and Business, Perbanas Institute - Jakarta. 75 students as respondents were selected using two stage cluster random sampling. Then three tests for all variables were given to the respondents. The data was used for analysis using SPSS multiple regression analysis. The result revealed that (1) prior knowledge in economics significantly influenced reading comprehension in business English text (2) the mastery of cohesion devices significantly influenced reading comprehension in business English texts (3) simultaneously both prior knowledge in economics and cohesion device mastery significantly influenced reading comprehension in business English texts.
\end{abstract}

Keywords:

Business English, prior knowledge in economics, cohesion devices, reading comprehension

\section{Introduction}

Prior knowledge has been widely discussed as an important factor in studying. It it is an essential element in gaining new knowledge. Encouraging learners to activate what they have already known about a topic will help them understand the text. Prior knowledge is also closely related to the disciplines the learners are studying. English for Business subject in Faculty of Business and Economics, Perbanas Institute-Jakarta is a part of English for specific purpose whose topics in Business English textbook are much related to economics and business.. Numerous studies have been conducted to identify the role of prior knowledge in reading. However, only a few studies on students' prior knowledge in economics are reported, especially in Indonesia.

English subject will focus on comprehending texts which are seen as a semantic unit. The meaning is tied by the relationship of elements in cohesion devices. Text cohesion occurs when text is interpreted as 
Volume 4 Nomor 1 Juni 2017

interrelated elements and one of the elements presuppose the other element. Students who are unable to identify these elements called cohesion devices will find the text more difficult to comprehend. Consequently, understanding the cohesion devices in a text is very important for students.

Reading comprehension is a complex task, which involve different cognitive skills and abilities. Indeed, when students are reading, they are not in passive condition. In fact they simultaneously do complex activities such as guessing, checking, making questions to themselves in order to understand a text. Many students still fail to understand text because they still consider that reading is a passive skill. For this reason, activating learners' prior knowledge and cohesion devices will help them comprehending the texts.

\section{Research Questions}

From the above identification of problems, research questions are as follow.

1. Does prior knowledge in economics help students comprehend business English texts succesfully?
2. Does cohesion device mastery help students comprehend business English texts successfully?

3. Simultaneously, will both prior knowledge in economics and cohesion devices mastery help students in comprehending business texts?

\section{Purpose of the Study}

This research is aimed at recognizing how prior knowledge in economics and cohesion devices affect students in comprehending business English texts, either partially or simultaneously.

\section{Scope of the Study}

The research will focus on prior knowledge in economics as external factor and cohesion devices as an internal factor in the text. Both are as independent variables. As the dependent variable is reading comprehension in Business English text.

\section{Significance of the Study}

This study has some beneficial outcomes:

1. It provides ways for students to comprehend the English business texts successfully. 
ISSN : 23557083

Volume 4 Nomor 1 Juni 2017

2. It helps educators to use strategies in teaching reading comprehension.

3. It helps educators prepare suitable materials for the learners in Business English class.

\section{Review of Literature}

\section{Background or Prior Knowledge}

Background knowledge or sometimes called prior knowledge plays an important role in understanding texts. Nunan (1993:115) defined prior or background knowledge as the world knowledge used by the readers in interpreting both speaking and written languages. Similarly, Beaumont (1990:16) stated that all readers in different stages will use their own prior knowledge when reading texts either in native or foreign language. In more details, Coady (1979:7) explained three factors consisting of higher level of conceptual capability, prior knowledge and process strategy will bring to a comprehension. Therefore, he said, people who have western world knowledge in learning English will be more successful compared to those who don't have this knowledge.
Chou (2011) studied the effects of vocabulary knowledge and prior or background knowledge in an EFL reading comprehension test. The study revealed that the students who were introduced with a list of vocabularies to study had performed better on reading comprehension when compared to those who relied on prior knowledge. So vocabulary building was needed, especially specific word related to the disciplines the students are studying. In contrast, Al Jahwari (2015) investigated three main aspects related to prior knowledge in EFL reading comprehension in Oman. The findings showed a strong agreement of the role of prior knowledge in text comprehension. It was confirmed by Mallik and Lodewijk (2010) who reported their findings that higher levels of mathematics and economics taken prior to university have a strong predictive power on students' performance.

\section{Schema Theory}

Prior knowledge in reading comprehension is closely related to schema theory. According to Bartlett, a psychologist who firstly introduced this term in 1930s, a schema is an 
active organization as a reaction to the past experience or past event. Schemata refer to background or prior knowledge that leads us to expect or predict features in our understanding of a discourse (Brown and George, 1983:248). Carrel and Eisterhold (1983) stated that schema is the abstract structure describing a concept saved in the memory. The interaction between concept in memory and information provided by a text will create a comprehension. From the above description, there are two important factors to be considered. Firstly memorizing and comprehending process are an active process. It implies that readers can interpret the text differently. The second, memorizing and comprehending are not static phenomena. It means that memory will vary in the long term. Readers's comprehension to a text today will be different from their comprehension tomorrow.

Furthermore, Carrel and Eisterhold also categorized schemata as content schemata and formal schemata. A content schema is prior knowledge related to a topic like knowledge about Mexican economy, history of Canada, etc. On the other hand, a formal schema is a prior knowledge related to organizational structure of formal texts. They mentioned also that a prior knowledge of a reader in comprehending texts is usually related to culture-specific knowledge. It can be concluded that the culture-specific knowledge of students of Perbanas Institute who mostly major in business and banking program is prior knowledge in economics.

\section{The Cohesion Devices}

Halliday and Hassan (1976:4) who firstly introduced cohesion categorized it into five elements; they are references, substitution, ellipsis, conjunction, and lexical cohesion. Nuttal (1982:89) specifically classified: references, substitution, ellipsis, and lexical cohesion as cohesion devices because they use signification to refer to what the speaker says or writer writes. References, substitution, and ellipsis do not directly state the message in the sentences. The messages can be traced from another part of the text. In contrast, conjunction is called discourse marker because it only 
Volume 4 Nomor 1 Juni 2017

signifies the relation within sentences or within discourse (Nuttal, 982:89). Furthermore, Cook (1990:14) defined cohesion devices as a formal tie between sentences and paragraphs.

In more details, Nunan categorized cohesion into grammatical cohesion which covers references, substitution, ellipsis, and conjunction. Then, the second is lexical cohesion which consists of reiteration and collocation.

References occurs when a word can not be semantically interpreted without relating it to another word in the text. Substitution takes place when a word is replaced by another word referring to similar meaning in order to avoid repetition. The difference between substitution and reference is that substitution lies in the relation between words, whereas reference between meanings. There are three types of substitution: nominal, verbal, and clausal. Ellipsis is the process of deleting an unimportant item that has been stated before in the text and it is changed by 'zero' or no item. Ellipsis has three types: nominal, verbal, and clausal. Conjunction is a word connecting sentences or clauses in the text.
Conjunction shows a 'logicalsemantic' relation between sentences rather than between words and structures. In other words, it is mostly grammatical but also involves lexical relation. There are four types of conjunction, namely additive, adversative, causal, and temporal. Lexical cohesion refers to semantically connected words in a text. Lexical cohesion devices include reiteration and collocation (He, Qinghsun, 2014:1).

Cooper (1984) studied the impact of cohesion devices on reading comprehension to a group familiar with English and group which was less exposed to English. The result indicated that both group had no difficulties in substitution and ellipsis but showed strong differences in lexical cohesion. Then, Ehrlich MF (1991) studied the cognitive operations involved in the processing of surface-cohesion devices for the construction of a coherent mental representation is a major issue in text comprehension. An experiment was carried out with two narratives presented in two versions: a highcohesion version and a low-cohesion version derived from the high version 
ISSN : 23557083

Volume 4 Nomor 1 Juni 2017

with the use of several devices--two anaphoric markers, changes in the temporal connective and word order, omission of the thematic sentence-without modification of the text content. The subjects read and immediately recalled a high-cohesion text and a low-cohesion text. The results showed that lowering cohesion produced an insignificant increase (8\%) in reading time, but a highly significant decrease $(25 \%)$ in recall performance. It appears that the subjects did not execute the processing required by the cohesion devices. The results are discussed with respect to models of sentence comprehension in comparison with text comprehension and metacognitive aspects of reading comprehension.

Hassanejad and Mollahosainy (2012) investigated the impact of cohesive devices on Iranian intermediate EFL students' reading comprehension. The results showed that cohesive devices helped students in a better understanding of English language texts. And $\mathrm{He}$, Qinghsun (2014) in his study reported that the lexical cohesion theory can help improve students' reading speed and accuracy and thus provide them with a new problem-solving method in reading comprehension.

\section{Reading Comprehension}

The teaching of reading comprehension is developing. Educators said that the failure in involving the linguistic meaning of a text to culture-specific knowledge in term of prior knowledge will not maximize the reading comprehension mastery. Concept of background knowledge has argued that reading is a passive activity. In fact, in reading a text, students must actively involve the guessing, predicting, checking, and evaluating activities (Grellet, 1990:8). Carrel supported this argument. Reading is not passive but active, even interactive activities (1992:1). Here, readers not only see written language and receive series of visual perception image, but they also should actively use their language knowledge, experience, conceptual ability to interpret written information. In other words, reading should be seen as the effort to reconstruct the writer's messages through the interaction between reader's background knowledge and text. The more the readers can guess or predict the text 
correctly, the less the confirmation is needed from the text. This comprehension process is called topdown process or represents conceptdriven process because the process is based on conceptual information. In top-down process, the activities include using background knowledge, scanning title and sub-titles, understanding pictures and graphs, skimming, guessing, making questions about the texts, separating important and unimportant information.

\section{Rosenblatt (1978), in} Moreillon (2007), developed a theory of reading as a transaction among the reader, the text, and the intention of the author. She posited that each reader brings his own feelings, personality, and experiences to the text and that each reader is different each time he revisits a particular text. Background knowledge is what the reader brings to the reading event. Each reader's interpretation and each reading of the text are potentially unique. This theory helps explain our individual responses to literature, art, and music and can be applied more broadly to our generalized responses in all areas of learning, including economics and business.
Theoretical Framework

It can be said that people will read by interacting their prior knowledge and the content of the text. If prior knowledge is not activated, meaning reconstruction as the important part in reading will not happen. The vast knowledge related to the text will accelerate the comprehension about the text. Therefore students' prior knowledge in economics will help them in comprehending the business English texts.

Cohesion is a semantic concept which refers to meaningful relationship within the text because text is not a group of separated sentences but it has interrelated meaningful sentences. A good text usually has meaningful relation which is explicitly characterized by the presence of cohesion devices like references, substitution, ellipsis, conjunction, and lexical cohesion. When students do not realize and do not understand these cohesion devices, they will feel difficult in comprehending the texts. Therefore, understanding cohesion devices will help students in comprehending the texts. 
Volume 4 Nomor 1 Juni 2017

It can be concluded that many factors influence the students in comprehending text. Some of them are prior knowledge and cohesion devices. Reading comprehension is the interaction between prior knowledge and the text. In addition, a text is called cohesive and coherent when it provides some cohesion devices to help readers understand the text. Therefore, if students can actively use their prior knowledge in economics and understand and realize the presence of cohesion devices in the texts, surely these will ease them in understanding business English texts.

\section{Method}

\section{Procedures}

In March-June 2015, a survey was conducted by distributing questionnaires or tests which were given to 75 Perbanas Institute students who were taking Englih for Business subject in Accounting and Finance Programs, Faculty of Economics and Business, Perbanas Institute, Jakarta.

The population was all Perbanas Institute students majoring in S1 Business and Financial Management and S1 accounting programs who were taking Business
English subject. 75 respondents were selected as sample using two stage cluster random sampling. The first step, three classes will be selected from the total classes which were taking Business English subject. Then, the second step, from each selected class, 25 students were taken as sample.

Several tests were used as the instruments to obtain the data. The tests consisted of:

1. Prior knowledge in Economics test. It was arranged based on economic concepts or terminologies found in macro and micro economics. The test was designed to measure students' prior knowledge in economics. Macro and microeconomic concepts or terms were selected based on the inter-textual principle from which the content of a text could be traced from the previous or succeeding texts. It meant that the topics concerning macro or micro economics in English textbook which were learned in Perbanas Institute all together helped comprehend the text which was reading. Data was gained by providing multiple-choice test with 
ISSN : 23557083

Volume 4 Nomor 1 Juni 2017

four options. The test consisted of 50 items. The correct answer would get 2 points. So the total scores was $50 \times 2=100$.

2. Cohesion device test. It was arranged to measure the ability to understand cohesion devices consisting of references, substitution, ellipsis, and conjunction (Grammatical cohesion components) in a business English text. Data was gained by providing multiplechoice test with four options. The test consisted of 25 items. Every correct answer would get 4 points. So totally the score was $25 \mathrm{X} 4$ $=100$.

3. English reading comprehension test. It was arranged by providing a text related to macro and micro economics. Data was gained by providing multiple-choice test with four options. The test consisted of 25 questions. Every correct answer would get 4 points. So totally the score was $25 \times 4=100$.
Validity and Reliability tests were previously held by giving the tests to a group of subjects consisting of 20 students. The validity of economic background knowledge was measured by using content validity test. It was done by providing the test whose materials were in line with the syllabus used in Perbanas Institute. The reliability test was held by measuring internal consistency of the test, using split-half test. Correlation Coefficient between odd items and even items in the tests was calculated.

The data from the prior knowledge in economics test (X1), cohesion devices test (X2), and Business English reading comprehension test (Y) was then statistically analysed by using SPSS multiple regression test.

\section{Findings and Discussion}

Based on the results of the tests given to the students, then the data were analysed by using SPSS-linear multiple regression. The data was reported in the tables below. 
Volume 4 Nomor 1 Juni 2017

Table 1. Frequency Distribution of Prior Knowledge in Economics, Cohesion Devices, and Reading Comprehension Test Scores

\begin{tabular}{|l|c|c|c|}
\hline & $\begin{array}{c}\text { Prior Knowledge in } \\
\text { Economics (X1) }\end{array}$ & $\begin{array}{c}\text { Cohesion Devices } \\
(\mathrm{X} 2)\end{array}$ & $\begin{array}{c}\text { Reading } \\
\text { Comprehension (Y) }\end{array}$ \\
\hline $\mathrm{N}$ & 75 & 75 & 75 \\
\hline Mean & 55.44 & 57.95 & 61.73 \\
\hline Mode & 62 & 72 & 70 \\
\hline Median & 58 & 60 & 65 \\
\hline SD & 10.95 & 13.49 & 10.64 \\
\hline Range & $30-78$ & $28-76$ & $35-80$ \\
\hline
\end{tabular}

Figure 1 showed the distribution of test scores of independent variables consisting of prior knowledge in economics (X1) and cohesion devices (X2), and dependent variable consisting of Business English text reading comprehension $(\mathrm{Y})$.

From prior knowledge in economics test, the highest score was 78 and the lowest was 30 . The mean score of the test was 55.44, median score was 58 , mode score was 62 , and the standard deviation was 10.95 . Then, from cohesion devices test, the highest score was 76, in contrast the lowest score was 28 . The average score was 57.95 , the median score was 60 , the mode score was 72 , and the standard deviation was 13.49. And finally, from reading comprehension test, the highest score was 80 , and on the other hand, the lowest was 35 . The average score was 61.73 , median score was 65 , mode score was 70 , and the standard deviation was 10.64.

\section{Classical Assumption Testing.}

Before multiple regression test was conducted, several tests consisting of multicolinearity, auto correlation, heteroscedasticity, and normality tests were performed.

In multicolinearity test, VIP score was 1.005 and Tolerance scores of both variables are 0.995. Because the scores of VIP were less than 5 or 10 , it can be said that there was no multicolinearity between both of independent variables. Therefore the linear regression model was free from multicolinearity.

In auto correlation test, Durbin-Watson Score was 1.602. When compared to DW table, it can be seen that with $\mathrm{k}=2$ and $\mathrm{n}=75$, the score was in the range of $1.571(\mathrm{dL})$ and 1.680 (dU). Therefore, it can be 
Volume 4 Nomor 1 Juni 2017

said that there was no autocorrelation in linear regression model in $\mathrm{p}$ value of 0.05 .

Then, the regression model was considered good if there was no heteroscedasticity. From the table of scattered plot, it was found that the data was scattered and didn't show a pattern. The heteroscedasticity test confirms the absence of heteroscedasticity at least at the 5\% level for all specifications. Therefore it can be said that the regression model was good because it showed homocedasticity. Furthermore, in normality test, from normal P-P plot diagram, it can be seen that the scores was scattered almost near the diagonal lines on the diagram. So it can be concluded that data has normal distribution.

\section{Ordinary Least Squares regression} $($ OLS $)$

To finds out the effect of prior knowledge in economics (X1)and cohesion devices (X2) as independent variables on students' comprehension in understanding English business text (Y), multiple regression test was used to analyse the data.

Table 2. Table of ANAVA

\begin{tabular}{|l|c|c|c|c|}
\hline \multicolumn{1}{|c|}{ Variables } & $\begin{array}{c}\text { Unstandardized } \\
\text { Coefficient }\end{array}$ & $\begin{array}{c}\text { Standardized } \\
\text { Coefficient }\end{array}$ & $\mathrm{t}$ & P-Value \\
\hline (Constant) & 20.92 & & 3.245 & 0.002 \\
\hline Prior Knowledge & 0.318 & 0.325 & 3.508 & 0.001 \\
\hline Cohesion Devices & 0.402 & 0.506 & 5.460 & 0.000 \\
\hline R-Square & 0.384 & & & \\
\hline F & $22.459(0.000)$. & & \\
\hline
\end{tabular}


Volume 4 Nomor 1 Juni 2017

The above table showed that $\mathrm{p}$-value for prior knowledge in economics was 0.002 which was less than $p=0.005$. It meant that prior knowledge in economics significantly influenced reading comprehension. For Cohesion devices, the p-value was 0.000 which was less than $\mathrm{p}=0.005$. This meant that cohesion devices also significantly influenced reading comprehension.

Finally, R-Square or coefficient of multiple determination for both of variables was 0.384 . And F score was $(0.00)$ which was less than $\mathrm{p}=0.05$. This meant that simultaneously both of prior knowledge in economics and cohesion devices had slightly significant influence on reading comprehension. This meant that only $38 \%$ could explain how both of variables influenced reading comprehension.

The $F$-ratio in the above ANOVA table tests whether the overall regression model was a good fit for the data. The table showed that the independent variables statistically significantly predicted the dependent variable $\quad 22.459$ in $p<\quad .0005$.

\section{Discussion}

The results indicate that both predictor variables give real contribution for criterion variable. However, mastery of cohesion gives bigger contribution. The fact which shows the positive relation between basic knowledge and reading skill is matched with schema theory. The theory states that there is an interaction between mind concept and the information from text. Tan Soon Hock research also shows majority will use their prior knowledge when they reconstruct any information from reading text. Similar result is also given by the research from Bransford and Johnson. The result which shows that mastery of cohesion has positive relation with reading skill is matched with Chapman research. He also adds that the age and experience will increase the ability to fill any missing cohesion in close text.

\section{Limitation}

There are some limitation occur in this research. The details are as follow:

1. Test which combined micro and macroeconomics for prior knowledge in economics variable did not explain the material components in detail.

2. Sample size is very limited. Total respondent is only 75 out of 448 
ISSN : 23557083

Volume 4 Nomor 1 Juni 2017

students as population. So the findings are not generalizabled to the whole students.

3. Only 4 components from 5 components of cohesion devices taxonomy that were analysed in this research. The four components (Grammatical cohesion) are reference, substitution, eliption, and conjunction. Meanwhile lexical cohesion is excluded.

4. The reading text that is being used is limited, which is only one. Using more texts and give variation will be better since the inter-textuallity will give deeper analysis for the research.

\section{Conclusion, Implication, and suggestion.}

\section{Conclusion}

Based on statistical analysis above, some conclusion may be concluded.

First, the prior knowledge in economics has significant effect on reading comprehension in business English texts. It means that a student who has high prior knowledge in economics will also have high ability in comprehending business English texts.
The second, the mastery of cohesion devices also has significant effect on reading comprehension in business English texts. So the more someone masters cohesion devices like references, substitution, ellipsis, and conjunction, the better his/her ability in comprehending business English texts is.

The third, multiple regression analysis shows that there is a significant effect of both prior knowledge in economics and cohesion devices mastery in comprehending in business English texts. It means that if someone has high cohesion device mastery and high economic background knowledge, he/she will also have high ability in comprehending English business texts. In other words, the coefficient determinant of 0.384 indicated that prior knowledge in economics and cohesion devices mastery simultaneously contribute only $38.4 \%$ to comprehending business English texts. However the cohesion devices have stronger effect on Reading comprehension on business English texts compared to the effect of prior knowledge in economics on reading 
Volume 4 Nomor 1 Juni 2017

comprehension to business English texts. It can be seen from coefficient of correlation 0.402 on cohesion devices which is higher than coefficent correlation 0.318 on prior knowledge in economics.

\section{Implication}

The research findings indicate that there is a significant effect of prior knowledge in economics in comprehending business English texts. This implies that reading problems is not entirely related to language problems. Lack of prior knowledge in economics can also be the reading problem. That is why prior knowledge should be activated in learning process because it will motivate students to learn. In some cases, students with less prior knowledge about a concept are activated by using advance organizer. Advance organizer is a statement about abstract concepts or terminologies which is introduced before the text is discussed. This will be a conceptual bridge between what a student has already known and a preposition in the text.

This research also shows that cohesion devices have significant effect in comprehending business
English texts. Business English texts in higher education are rarely in the form of discourses but texts. In general, texts will use cohesion devices like references, substitution, conjunction, or ellipsis to connect ideas within texts. Therefore the mastery of cohesion devices for students in comprehending text is unavoidable. The next questions are which cohesion element is considered difficult for students and how is the strategy to help them master cohesion devices.

As mentioned before, comprehending texts can be performed by using two approaches. The first one is bottom-up processing approach which starts comprehending the text by looking at the smallest element like sentence and developing to larger elements such as sentences or paragraphs in the text. In contrast, topdown processing approach starts from broader elements and moves to more specific elements. Some of these elements are prior knowledge in economics and cohesion devices. The mastery of prior knowledge in economics will be more successful if bottom up processing approach is exercised. On the other hand, cohesion 
ISSN : 23557083

Volume 4 Nomor 1 Juni 2017

device mastery will be more effective when top-down processing approach is used. Furthermore, bottom up processing approach is better if this is used in a lower language level but topdown approach will be promising if this is used for higher level. However, interactive approach which combines these two approaches is considered better because using this approach will enable lecturer to develop students' mastery in prior knowledge in economics and cohesion devices.

\section{Suggestion}

In the light of the results of the research, some suggestions will be offered in the following.

First, prior knowledge in economics should be activated since meaning is understood through the interaction between prior knowledge in economics and text. In the classroom, it can be exercised by guessing or predicting activity, finding main ideas, or connecting ideas. When the activities are divided into prereading, reading, and post reading activities, then guessing will be placed at the pre-reading activity. Furthermore, the usage of diagram or schema which sketch out the content of the text in pre-reading activity will accelerate the process of reading comprehension. Last but not least, the teaching of ore more specific prior knowledge (content schemata). In this case, the concepts or terminologies in economics should be connected to students' environment.

The second, in order to understand cohesion devices and be able to use them correctly without being burdened by linguistic terms, the best strategy is bottom up approach. For example, references can be introduced by identifying the referent prior to underlined word. Next, substitution elements can be taught by replacing the underlined word to another word which has similar meaning. Then ellipsis element in a paragraph can be taught by summarizing the paragraph through ellipsis process. Finally, conjunction is taught by asking the students to insert some conjunctions in cloze tests.

The third, the strategy in teaching reading comprehension on business English texts often uses bottom up approach by which the smallest elements are introduced first, then gradually move to a wider element. In this case, language is seen 
as a formal language system which consists of separated or disconnected words or sentences without considering text as a meaningful unit. Therefore it is better if a lecturer uses interactive approach in which all elements will cooperate to comprehend business English text.

The fourth, in Perbanas Institute case, English for specific purpose will be better if it is offered after students take the subjects related to economic background knowledge. The fifth, instructors' prior knowledge in economics may have an effect on student performance. Hence, the economic knowledge of lecturers who are mostly from language disciplines should be continously enhanced.

\section{References}

Al-Jahwari, Yahya.(2015). Prior Knowledge in EFL Reading Comprehension: Omani Teachers' Perspectives \& Classroom Strategies. In International Journal of Applied Linguistics \& English Literature, ISSN 2200-3592 (Print), ISSN 2200-3452 (Online), Vol. 4 No. 1; January 2015. Copyright (C) Australian International Academic Centre, Australia

Anderson, Eleanor (1992). Changes. Buckingham: Open University Press

Beaumont, Mike (1990). Teaching Reading Skills in A Second Language: What Skills Readers Know and Do When They Read. (Unit 1 ). Menchester Center for English Language Studies in Education (CELSE), Manchester University

Birch, E.R., Williams, A., 2009. The determinants of academic performance in first year university economics. In: Robinson, T., Tang, T., Fletcher, A. (Eds.), Proceedings of the 14th Annual Australasian Teaching Economics Conference, QUT, pp. 13-25

Brown, G., \& Yule, G. (1983). Discourse Analysis. London: Cambridge University Press. http://dx.doi.org/10.1017/CBO9780511805226

Cameron, Michael P. and Steven Lim. Recognising and building on freshman tudents' prior knowledge of economics, New Zealand Economic Papers, 2015 Vol. 49, No. 1, 22-32, http://dx.doi.org/10.1080/00779954.2013.863721

Carrel, P. L. and J. C. Eisterhold (1983)."Schema Theory and ESL Reading Pedagogy" in TESOL Quarterly. 17, 553-573.

Coady, James (1979). A Psycholinguistic Model for ESL Reader. In Mackay, Ronald et al. Reading in A Second Language: Hypotheses, Organization, and Practice. Rowley: Newbury House Publisher Inc 
Cook, Guy (1989). Discourse. Oxford: Oxford University Press

Durden, G.C., Ellis, L.V., 1995. The effects of attendance on student learning in principles of economics. Amer. Econ. Rev. 85 (2), 343-346

Ehrlich MF. The processing of cohesion devices in text comprehension.In Psychol Res. 1991;53(2):169-74. Laboratoire de Psychologie Expérimentale, CNRS URA 316, Université René Descartes, Paris, France.

Halliday, M. A. K. and R. Hasan (1976). Cohesion in English. London: Longman UK Group Limited

Happ, Roland, Manuel Förster, Olga Zlatkin-Troitschanskaia, Vivian Carstensen. Assessing the previous economic knowledge of beginning students in Germany: Implications for teaching economics in basic courses. Citizenship, Social and Economics Education 2016, Vol. 15(1) 45- 57, (C) The Author(s) 2016

Hasanejad, Mohammad Reza and Mohammad Reza Mollahosainy. The Impact of Cohesive Devices on Iranian Intermediate EFL learners' Reading Comprehension Skills. in Iranian EFL Journal, Volume8-3 June 2012. ISSN On-line: 1836-8751, ISSN Print: 1836-8743

He, Qinghsun A Study of Lexical Cohesion Theory in Reading Comprehension. In International Journal of English Linguistics; Vol. 4, No. 6; 2014, ISSN 1923869X E-ISSN 1923-8703. Canadian Center of Science and Education

Mallik, G., Lodewijks, J., 2010. Student performance in a large first year economics subject: Which variables are significant? Econ. Pap. 29 (1), 80-86.

Moreillon, Judi.( 2007) Collaborative strategies for teaching reading comprehension : maximizing your impact . Chicago: The American Library Association.

Nunnan, David (1993). Introducing Discourse Analysis. London: Penguin Book Ltd.

Nuttal, Christin. (1982).Teaching Reading Skills in A Foreign Language. London: Heineman Educational Books

Oakhill.Jane, Kate Cain, Carsten Elbro. (2015). Understanding and teaching reading comprehension : a handbook., New York: Routledge.

Peter Tze-Ming Chou, Peter. (2011).The Effects of Vocabulary Knowledge and Background Knowledge on Reading Comprehension of Taiwanese EFL Students. Electronic Journal of Foreign Language Teaching . Vol. 8, No. 1, pp. 108-115. Singapore: Center for Language Studies, National University of Singapore 